\title{
THE GIANT ASPEN
}

\section{R. ROBINSON, 1119 Temperance Street, Saskatoon, Saskatchewan}

In June, 1906, my father filed on a homestead on the N.E.6-36-14, W. 2 nd. This was father's third homestead, the location ten miles east of the village of Quill Lake. At that time, and for several years later, there was one poplar tree growing on this quarter which we will call the "giant aspen" (Populus tremuloides). My older brother, Clair, states that the species name is correct. The Aspen Poplar was used almost exclusively as firewood and was much superior to the Balsam Poplar (Populus balsamifera), locally referred to as black poplar because of the much darker colored bark. There were scattered trees of this species in our community but it would comprise less than one percent of the poplar population.

When cut down in 1910 , the giant aspen measured 23 inches in diameter some two feet above ground level. The height of this tree was about 45 feet. As a younster I well recall this poplar, the crown towering well above the neighbouring trees. The land in that district is relatively level and this tree had no apparent advantage as regards moisture supplies.

A further reference to tree growth in this community may be in order. On the quarter section, above mentioned, and on the east half of section 7 there was a fair stand of large aspen poplars, occupying an area of about 250 acres. They were not as large as the giant aspen but would range from 14 to 16 inches in diameter. In the winter of 1907-08 W. Ratz of Quill Lake operated a small sawmill on section 7. Power was provided by a stationary steam engine burning slabs. Saw logs were cut by the settlers and sawed into rough lumber.

During the period 1904 to 1910 , when this community was settle there were numerous bluffs of aspe poplar ranging up to 12 inches diameter. These trees were used e; tensively in the building of log house and barns.

It is my opinion that the inform tion presented here might be wor recording for the following reason:

(a) The size and probable age of th giant aspen; and

(b) The location of this small stand forest trees in what is common referred to as the park belt. Th nearest lumbering area at th time was 23 miles to the north the Nora district, and again son 25 miles northeast in the $\mathrm{N}$ Mountain community.

Assuming that the giant aspen wa particularly vigorous specimen it $m$ have been a small sucker or seedli in 1850 . The other large poplars, $c$ for lumber, perhaps commenc growth in the early 1860's. (In t older section of Nutana, Saskatoc there are two trees of the Eastern C tonwood (Populus deltoides) th were planted in 1911. This is a rap growing species and these trees now about 67 years of age and proximately 30 inches in diameter). the records of the fur traders a other early western travellers there frequent reference to widespre fires on the plains and the adjace parklands. It seems probable tha fire swept through this territo north of the Quill Lakes, in the 1860 's. The extensive stands of you aspen poplars developed during next 36 years. The small acreage large poplars, in some manner, caped the fire. By 1907 these tr would have reached an age of $a b$ 45 years and the old giant, in 1910 age of some 60 years. 